\title{
Att förhålla sig till ändligheten i livet och strategier för "framgångsrikt döende"
}

\begin{abstract}
Successful dying. Later life strategies to cope with the finiteness of life.
This article aims to explore how older people relate to the finiteness of life. Unlike many other similar studies, this study focuses on older people outside palliative care and residential care, those who are still active and engaged in society. When, and in what ways do finiteness of life become apparent to them in their everyday lives? What strategies do they use to manage awareness of the finiteness of life? In 2015, data was collected via six focus group occasions with people aged 69-90. The result show that finiteness of life was something that all respondents were occupied with almost daily and in several ways. In most cases with ambiguity and even fear for the uncertainty of the future, but also with a feeling that the awareness of finitude made the present more valuable. Death was manifested in the respondents' everyday lives, as something to be postponed, planned and administered by the types of self-disciplining techniques that are significant for successful ageing. I therefore conclude that these norms and techniques of successful ageing have expand into the field of ways of practice dying and thereby, become norms and techniques of successful dying.
\end{abstract}

Key words: Finitude, successful dying, death, successful ageing, later life, ageing

HISTORISKT SETT HAR människan alltid haft en närhet till döden. Döden har, så att säga, varit en naturlig del av livet. Döden var något som kunde inträffa oavsett ålder och därför levde människor förr med en annan insikt om att livet var ändligt. Sedan slutet av 1800-talet har döden alltmer kommit att förknippas med att vara äldre. Till stor del beror denna förskjutning på den ökade förmågan att bota sjukdomar och den minskade barnadödligheten, vilket gjort att det faktiska döendet i allt högre utsträckning sker vid hög ålder och i allt högre utsträckning också på institution (Leishman \& Moir 2009). Därför kan det hävdas att döendet och döden har förskjutits från det normala i livet till något som inte längre tillhör livet (Baars 2016; Lamers \& Williams 2016). Samtidigt kan det tänkas att medvetenheten om döden, eller kanske snarare livets ändlighet, kan påverka människor och vara mer eller mindre påtaglig i olika sekvenser av livet, till exempel vid sjukdom, vänners eller familjemedlemmars bortgång, uppbrott och så vidare, även om den konkreta döden förflyttats från hemmen in på institution. Det handlar då om en teoretisk medvetenhet om att livet är ändligt 
som kan påverka individers liv och självbild i nuet. Just sannolikheten att livet skall ta slut och känslan av närhet till slutet är vad denna artikel skall behandla. Närmare bestämt hur äldre personer förhåller sig till denna känsla av ökad sannolikhet och närheten till slutet.

Det har i olika studier beskrivits hur medvetenhet om att en levt många fler år än en har kvar leder till ett ändrat perspektiv på tid och även på livet som sådant (Elchardus \& Smits 2006; Woodspring 2016). Flertalet studier har brottats med fenomenet att det verkar som att individer upplever att livet går fortare ju längre tid de har levt (Janssen, Naka \& Friedman 2013). Samtidigt går det inte att påvisa att äldre personer på något sätt har en annorlunda tidsuppfattning än yngre personer (ibid.) I en kvalitativ intervjustudie med deltagare från den så kallade babyboom-generationen i England, beskriver Woodspring (2016) hur komplicerade relationer mellan tid, kropp och åldrande påverkas av individernas biografiska erfarenheter och reaktioner på offentliga bilder av åldrande. Dessa offentliga bilder bygger många gånger på utsagor om "framgångsrikt åldrande" (successful ageing).

I artikeln Successful aging beskriver författarna Rowe och Kahn begreppet som att:

We define successful aging as including three main components: low probability of disease and disease-related disability, high cognitive and physical functional capacity, and active engagement with life (Rowe \& Kahn 1997:433)

Frågan om vad "active engagement with life" är besvarar författarna själva på nästa sida med orden: "An activity is productive if it creates societal value, whether or not it is reimbursed" (Rowe \& Kahn 1997:434). Den moraliska undertonen i artikeln om samhällsnytta och ansvarighet går inte att missuppfatta. Åldrandet är inte individuellt, $i$ alla fall inte det framgångsrika åldrandet. Ett framgångsrikt åldrande genererar alltid nytta för kollektivet. I en artikel i The American Journal of Geriatric Society, används begreppet "framgångsrikt döende" (successful dying). Det är en litteraturöversikt som är ämnad att ligga till grund för en dialog om hur samhället kan förbättra villkoren för döden och döendet. Studien innefattar utsagor från såväl patienter som familjemedlemmar och personal. Resultatet visar att de viktigaste faktorerna för en "framgångsrik död" är respekt för preferenser kring vård och hur döendet sker, frånvaro av smärta, känsla av att vara färdig med livet, värdighet, existentiell övertygelse och känslomässigt välbefinnande (Meier, Gallegos, Montross Thomas m.fl. 2016).

Jag tänker ta avstamp i dessa begrepp om framgångsrikt åldrande och framgångsrikt döende i min studie av hur äldre personer förhåller sig till livets ändlighet. I motsats till författarna av ovanstående artiklar har jag dock valt att ha ett problematiserande perspektiv på såväl det framgångsrika åldrandet som det framgångsrika döendet. Det perspektiv jag anlägger utgår från den kritiska gerontologin och ålderssociologin, där flera forskare har påpekat hur starkt dominerande diskursen om det framgångsrika åldrandet är i synen på åldrandet och livsloppet i dagens samhälle. Ur ett kritiskt perspektiv blir det tydligt att diskursen om ett framgångsrikt åldrande inte bara uppmuntrar till aktivitet utan även gör aktivitet till en skyldighet, genom att betona för 
allmänheten att med förmågan att åldras framgångsrikt följer också skyldigheten att åldras framgångsrikt (Katz 2000; Rozanova 2010; Timonen 2016).

Vid tolkningen av vem som åldras framgångsrikt och vem som inte gör det blir jämförelser en viktig faktor. Forskning visar också att jämförelser med andra personer i samma ålderskategori spelar en stor roll för identifikation liksom för hur äldre uppfattar det egna åldrandet och den egna hälsan (Gilleard \& Higgs 2000; McHugh 2000; Jolanki 2009; Bennett \& Gaines 2010). Baars (2017) menar att en viktig skillnad mellan hur människan historiskt förhållit sig till sitt åldrande och ändligheten är att det historiskt sett funnits en större acceptans för att livet är ändligt och att viljan att kontrollera sitt åldrande har därför inte varit så påtaglig som den blivit i dagens samhälle. Utmärkande för samtidens förhållande till livets ändlighet och livsloppet är att människan i allt större utsträckning söker efter strategier, teknologier och metoder för att kontrollera och förskjuta ändligheten.

Men allt i åldrandet går inte att kontrollera. Ballard, Elstone och Gabe (2009) visar att kvinnor som går igenom klimakteriet på ett tydligt sätt beskriver sitt åldrande som ett privat, inre åldrande kopplat till kroppens förändringar (till exempel sviktande minne, upphörande ägglossning och menstruation) och ett yttre offentligt åldrande kopplat till kvinnlighet och synliga ålderstecken (till exempel grått hår, rynkor, tunnare hår, hängande hud). Kvinnorna uttrycker att de uppfattar det privata åldrandet som mer förutbestämt och opåverkbart än det offentliga åldrandet. Exempelvis beskrivs förlusten av den reproduktiva förmågan som något okontrollerbart som deras kroppar bara gör mot dem utan att de har möjlighet att påverka vad som händer.

I studien av Ballard med flera blir det således tydligt att det är de kroppsliga förändringarna som gör informanterna uppmärksamma på att de är på väg in i ett nytt stadium i livet och att denna förflyttning till stor del ligger utanför deras kontroll. Det är något som kroppen gör mot dem, något oundvikligt som också för dem närmare ändligheten. För även om ändligheten inte är på förhand given så blir sannolikheten för att livet skall ta slut större ju äldre en människa blir (Weiss \& Lang 2012; Weiss 2014; Baars 2016) - ju längre tid en har levt desto mindre tid har en kvar att leva. Som nämnts tidigare är det den ökade sannolikheten att livet skall ta slut och känslan av närhet till slutet som denna artikel skall behandla. Till skillnad från många andra liknade studier, som främst ägnat uppmärksamhet åt äldre inom palliativ vård eller på äldreboenden, fokuserar den här studien på äldre som fortfarande är aktiva och engagerade i samhället. I studien ställs frågor som: Hur resonerar informanterna om livets ändlighet? När och på vilka sätt blir ändligheten påtaglig för dem i deras vardag? Vilka strategier använder de för att hantera denna medvetenhet om livets ändlighet?

\section{Teoretiska utgångspunkter}

Åldrandet är inte endimensionellt utan har tvärtom många olika dimensioner som vävs samman i en komplicerad struktur av biologi, kultur, genus och sociala förhållanden. Åldrandet kan erfaras som faser i livet (biografisk åldrande), markerade av uppbrott eller viktiga händelser i livet, (socialt åldrande) i interaktion med andra människor 
och (förkroppsligat åldrande) hur jag märker av åldrandet i min kropp (Andersson, Lukkarinen Kvist, Nilsson m.fl. 2011).

Karl Jaspers (1971[1938]) beskriver förlust av vänner eller familjemedlemmar, misslyckanden med att nå livsmål, förlust av personliga förmågor eller avsaknad av mening med livet som gränssituationer. Det är, menar han, i situationer som dessa som livets ändlighet blir tydlig för individen. Utmärkande för dessa gränssituationer är att de, utöver att de gör individen uppmärksam på livets ändlighet, också åtföljs av känslomässiga reaktioner i form av till exempel oro, en förhöjd känsla av nuet eller skuld. Känslorna kan vara såväl positiva och negativa och människors respons inför dessa gränssituationer varierar. Det kan handla om strategier för att undvika, förneka, distansera sig, men också strategier som innefattar konfronterande och ett omvärderande av den nuvarande livssituationen. Gränssituationerna, och hur en människa väljer att hantera dem, formar deras upplevelse av det egna livet i nuet, åldrandet och tolkningen av sin framtid. Gränssituationerna i sig är inte bundna till kronologisk ålder, även om jag i denna artikel använder dem för att analysera hur äldre människor förhåller sig till livets ändlighet. Enligt Jaspers (1971[1938]) är gränssituationer snarare en del av det levda livet, något som erfars oavsett ålder.

En del av livet, och föreställningarna om en framtid, är oundvikligheten, det vill säga det som inte går att kontrollera och som med nödvändighet kommer att inträffa. En av de sakerna är döden. Moran (2015) menar att eftersom det oundvikliga är något som finns i medvetandet i nuet så blir det också en del av upplevelsen av nuet. Vetskapen om att vi kommer att dö någon gång i framtiden påverkar vår upplevelse av livet i nuet. På så sätt påminner Morans utsagor om Baars (2017) teoretiserande kring att "praktisera döende" (practice dying). Det finns ingen bra svensk översättning av Baars engelska begrepp practice dying eftersom engelskans practice innefattar betydelser såsom att öva sig i något, att utöva något och att tillämpa eller praktisera något. Det svenska ordet praktisera förknippas kanske oftast med just att tillämpa eller utöva något och inte lika ofta med att öva sig i något. I artikeln skall dock begreppet "praktisera döende" förstås utifrån samtliga ovanstående aspekter. Det vill säga som något som övas, utövas och tillämpas. Baars (2017) menar att det finns en utbredd föreställning om att ändligheten, eller det ändliga livet är liktydigt med insikten om att en människas liv har ett slut och att alla människor förr eller senare kommer att dö. Baars problematiserar denna bild genom att hänvisa till Platons devis om att "praktisera döende". Baars menar att ett "praktiserande av döende" inte är samma sak som döendet eller motsatsen till liv, utan tvärtom ett sätt att leva. Ett sätt att integrera medvetenheten om livets ändlighet som kan leda till en förhöjd upplevelse av livet i nuet och tillförsikt inför framtiden.

Moran problematiserar oundvikligheten genom att dela in den i ett att och ett hur. Även om vetskapen finns att något oundvikligen kommer att inträffa i framtiden så innebär det inte en kunskap om hur detta kommer att ske. Detta hur öppnar upp för en osäkerhet och kanske även ett behov av att ta till strategier för att lägga till rätta, för att kunna återskapa känslan av kontroll över sitt eget livslopp (Moran 2015).

Tidens gång kan också upplevas som förändringar i kroppen (förkroppsligad tid), 
nya rynkor, gråa hårstrån och så vidare (Andersson, Lukkarinen Kvist, Nilsson m.fl. 2011; Woodspring 2016). I sociologen Bryan S. Turners verk synliggörs intresset för normalitet och avvikande i relation till kroppsliga uttryck och förändringar. Kroppen som föremål för styrningspraktiker eller olika sätt att kontrollera kroppar står här i fokus. Förändringarna eller ingreppen i kroppen markerar övergången från en livsfas till en annan men också från en identitet till en annan. Men förändringar i kroppen behöver inte vara förändringar som människor administrerar, utan det kan också vara förändringar som sker i kroppen utan mänsklig inverkan och som markerar övergången från ett stadium till ett annat (Turner 1987, 1992, 1996). Här kan jämföras med den tidigare nämnda studien om kvinnor i klimakteriet (Ballard, Elstone \& Gabe 2009). Dessa kroppsliga förändringar, som markerar övergången från ett stadium till ett annat, kan också förhållas till de gränssituationer som nämnts ovan. De utgör det kroppsliga åldrandets gränssituationer.

\section{Metod}

I den här studien har jag följt en grupp äldre personer genom sammanlagt sex fokusgruppstillfällen under året 2015. De personer som ingick i fokusgruppen varierade i ålder, den äldsta var 90 år och den yngsta 69 år. Totalt ingick fem kvinnor och nio män i fokusgrupperna. Vid första tillfället gjordes ett försök att dela upp gruppen i två fokusgrupper, men det resulterade i att den ena gruppen blev väldigt tyst. Därefter genomfördes återstående fem tillfällen i storgrupp. Målet var att fokusgruppen i så stor utsträckning som möjligt skulle bestå av samma människor vid varje tillfälle men det kunde inte uppnås. Gruppen har i stort sett varit den samma men vid något tillfälle var någon sjuk eller kunde inte vara med av någon annan anledning. Bedömningen är dock att den lilla variationen i gruppens sammansättning under de sex fokusgruppstillfällena inte har påverkat resultatet.

Samtliga informanter var pensionerade och levde aktiva liv på så sätt att de deltog $\mathrm{i}$ studiecirklar, ägnade sig åt regelbunden fysisk träning, var engagerade i ideellt arbete och så vidare. Några av dem drogs med kroniska sjukdomar och nedsatt hälsa. I gruppen fanns en överrepresentation av akademiker, framför allt lärare och ingenjörer.

För att finna informanterna sökte jag aktivt efter seniorkurser (det vill säga kurser som benämnde sig som seniorkurser och därmed hade definierat sig som speciellt lämpliga för seniorer) och fann en kurs som pågått under längre tid. Mitt mål med att söka deltagare via en seniorkurs var att finna en homogenitet av aktiva äldre deltagare som går en och samma kurs men en heterogenitet vad gäller ålder, kön, livserfarenheter och så vidare. Just kombinationen av homogenitet och heterogenitet bland deltagarna är en värdefull faktor för att få till stånd bra fokusgruppdiskussioner (Dahlin-Ivanoff 2018).

Kursledaren kontaktades och jag introducerades för deltagarna vid ett kurstillfälle där jag presenterade studien och efterfrågade deltagare. Informationen gavs muntligt och skriftligt genom ett informationsbrev som deltagarna fick med sig hem. De deltagare som var intresserade av att delta lämnade skriftligt samtycke. Jag valde medvetet att söka efter informanter som kände varandra genom att gå samma kurs. Det finns 
både fördelar och nackdelar med detta. Vissa menar att det är mer fördelaktigt med informanter som inte känner varandra eftersom det skapar ett öppnare diskussionsklimat, medan andra menar att just det faktum att informanterna känner varandra skapar ett öppnare diskussionsklimat. Det finns också diskussioner om huruvida det påverkar gruppdynamiken positivt eller negativt att informanterna redan är del av en existerande grupp (Bryman 2016; Dahlin-Ivanoff 2018). Som ledare i fokusgrupperna har jag varit medveten om det ovanstående och vid varje tillfälle aktivt arbetat med öppna frågor, riktade frågor, sammankopplande reflektioner, uppmuntran och delaktighet för att få alla att bli en del av dynamiken (Dahlin-Ivanoff 2018). Så här i efterhand kan jag konstatera att samspelet i fokusgrupperna varit mycket bra. Det har funnits såväl samstämmighet som dynamiska diskussioner. Klimatet har varit öppet och förtroendefullt, något som informanterna själva ansåg hade fört dem närmare varandra. Gruppen har även haft en självreflekterande och terapeutisk funktion för flera av deltagarna.

Varje fokusgrupptillfälle har följt en tematik med nyckeldiskussionsfrågor, men eftersom fokusgruppdiskussioner är en explorativ metod (Dahlin-Ivanoff 2018) har det funnits utrymme för fria associationer och ibland även utsvävningar. Jag har agerat gruppledare under diskussionerna och under fokusgrupptillfällena har ytterligare en forskare varit med som en biträdande moderator (Dahlin-Ivanoff 2018) för att komplettera med uppföljande frågor när jag som gruppledare förbisett något. För att verifiera tolkningarna har den medföljande forskaren varit med i diskussioner om tolkningar och analyser efter varje fokusgrupptillfälle (Bryman 2016).

Teman för fokusgrupperna var: Populära och offentliga föreställningar om att åldras; Äldre, senior, gammal; Brytpunkter i livet; Mitt åldrande; Var står jag i dag och Hur ser min framtid ut? Tanken har varit att under fokusgrupptillfällena fånga upp ett livsloppsperspektiv, det vill säga att genom tillbakablickar finna de händelser i livet som varit viktiga för hur informanterna ser på sig själva och sitt åldrande i dag och i framtiden. Avsikten var också att kunna relatera offentliga bilder av åldrande till uppfattningar om det egna åldrandet. Det kollektiva reflekterande som fokusgruppen innebär är värdefullt just för att fånga och utforska hur personer tänker och talar om valda ämnen (Bryman 2016; Dahlin-Ivanoff 2018). Det är intressant i sig att utforska hur individuella erfarenheter och reflektioner diskuteras i gruppen och resulterar i ett gemensamt reflekterande och ibland även kollektiva slutsatser. De första fokusgrupperna inleddes därför med diskussioner om offentliga bilder av åldrande. Det fanns en metodologisk poäng i att börja i det allmänna eftersom det gav mig en möjlighet att utveckla relationen med informanterna innan vi kom in på de mer personliga och känsliga ämnena (Dahlin-Ivanoff 2018). Vid första fokusgrupptillfället samlades också information om deltagarnas namn, ålder, kön och tidigare yrke in skriftligt (Bryman 2016).

För att analysera materialet har samtliga fokusgrupper spelats in och sedan transkriberats. Det transkriberade materialet har sedan kodats och analyserats och tematiserats med hjälp av tematisk analys, där materialet har strukturerats efter teman och underteman (Bryman 2016). I analysen beaktades särskilt sammansättningen i gruppen utifrån yrke, utbildning, ålder och kön. I den här artikeln presenteras framför allt 
resultat som varit övergripande och i låg utsträckning påverkats av ovanstående faktorer. I resultatet noteras de skillnader som aktualiserats.

I studien har de forskningsetiska principerna beaktats och samtliga informanter har lämnat informerat samtycke. Studien godkändes av Regionala etikprövningsnämnden i Lund den 6 mars 2013.

\section{Resultat}

Trots heterogeniteten i gruppen föreföll det finnas en gemensam uppfattning om det viktiga i strävan efter det framgångsrika åldrandet och det framgångsrika döendet. Deltagarna var dock inte helt eniga i vad som skulle anses som "framgångsrikt". Det enda som egentligen enade dem i synen på vad som var framgångsrikt var att de själva skulle ha kontrollen över förloppet. Att ha kontroll var en framgångsfaktor i sig. På så vis följer informanternas resonemang Baars $(2016,2017)$ teoretiserande om att det $\mathrm{i}$ samtiden blivit allt viktigare att ta kontroll över eller förskjuta ändligheten.

Något annat som förenade informanterna i deras diskussion om ändligheten var resonemangen kring att det inte var ändligheten i sig som skrämde dem utan det var vägen dit som kändes hotfull. Informanternas utsagor stämmer väl överens med Morans (2015) tes om oundvikligheten som uppdelad $\mathrm{i}$ att individen är medveten om livets ändlighet och hur individen hanterar denna vetskap. Jag har därför valt att strukturera resultatdelen utifrån dessa att och hur. Resultatet struktureras följaktligen i temana 1) förhållningssätt till livets ändlighet (att) och 2) strategier för att ta kontroll över livets ändlighet ( $h u r)$. Tema 1 struktureras vidare utifrån följande underteman: Socialt åldrande och gränssituationer - förhållningssätt till livets ändlighet; Förkroppsligat åldrande och gränssituationer - att känna sig gammal.

\section{Förhållningssätt till livets ändlighet - Att}

Förhållandet till livets ändlighet återkom vid varje fokusgrupptillfälle oavsett vilket tema som diskuterades och det var påtagligt att detta var en stor del av informanternas vardag. Att livet var ändligt och att denna ändlighet nalkades gjorde sig påmint på många sätt samtidigt: inifrån kroppen (förkroppsligat åldrande), utifrån omgivningen, genom att se sig $\mathrm{i}$ spegeln eller genom att spegla sig $\mathrm{i}$ andra (socialt åldrande) (Andersson, Lukkarinen Kvist, Nilsson m.fl. 2011). Informanterna uttryckte att livets ändlighet nu hade blivit påtagligt för dem på ett sätt som det inte tidigare hade varit i deras liv. Då hade livets ändlighet gjort sig påmind när familjemedlemmar eller vänner gått bort men ändligheten hade hela tiden handlat om någon annans livslopp. Nu upplevde de på ett helt annat sätt hur ändligheten handlade om deras eget livslopp, vilket var en känsla och en medvetenhet som flera av dem uttryckte att de hade svårt att hantera.

\section{Socialt åldrande och gränssituationer - förhållningssätt till livets ändlighet}

Under fokusgrupperna diskuterade informanterna sin uppväxt, förhållandet till föräldrarna samt mor- och farföräldrar som förebilder men också som avskräckande exempel vad gäller åldrande. Det var tydligt hur informanterna återkom till vissa berättelser om 
uppbrott eller relationer i deras liv som varit extra betydelsefulla för tolkningen av det egna åldrandet. I de retrospektiva reflektionerna uppstod också resonemang kring hur lång tid som hade levts och hur lite tid som var kvar. En sådan berättelse var Gunnars historia om hur han upplevde att tiden gick allt fortare ju äldre han blev.

Gunnar: Men om man då tänker efter hur snabbt de tio sista åren har gått: jag hade just den reflektionen igår kväll, alltså tittade tio år tillbaka och tio år framåt. Eva: Ja det är oerhört lite man har kvar.

Reflektionen om tidens gång och hur snabbt de sista tio åren gått uppstod första gången när vi diskuterade pensionering och hur informanterna hade föreställt sig livet som pensionär och hur det sedan hade blivit. Att tiden verkar gå snabbare när en blir äldre är, vilket nämndes tidigare i artikeln, något som besvärat tänkare och forskare i över flera århundraden (Janssen, Naka \& Friedman 2013). När experiment gjorts kring tidsuppfattning $\mathrm{i}$ olika åldrar går det dock inte att påvisa någon skillnad $\mathrm{i}$ hur äldre och yngre uppfattar tiden som sådan (ibid.). Skillnader i hur tid upplevs kan snarare tänkas ha att göra med den relativa levda tiden. Det vill säga: om jag har levt tio år så upplevs tio år som en lång tid, eftersom det är hela min hittillsvarande livslängd. Men ställt i ljuset av att en levt sjuttio år så blir tio år en relativt kort tid (Weiss \& Lang 2012; Weiss 2014; Baars 2016). När en därför, som den 70 -åriga informanten i citatet ovan, tänker tillbaks på de senaste tio åren och vad som hänt under dessa, och samtidigt drar slutsatsen att tio år kanske är ungefär vad jag har kvar att leva, så upplevs tio år som en oerhört kort tid.

Erfarenheter av att ha kort tid kvar kunde också komma genom påminnelser från omgivningen. Ett exempel är när Linn berättar om hur hennes dotter börjat fundera på vad som ska hända i en framtid när hennes mor inte längre finns kvar.

Linn: Jag har mer, alltså jag har en dotter som det har varit mycket bekymmer med, handikappad, och hon själv, nästan tar avstånd från mig nu för hon säger: "du ska ju dö snart mamma. Hur ska det gå för mig om inte jag lär mig att klara mig nu?” Så hon har själv tagit tag i det där. Och ja, det är ju rätt chockerande att höra sånt. Men det är ju alldeles rätt reflektion hon gör. Hur ska det gå för henne om jag? För jag har ju vräkt mina tjänster på henne för det har varit så hemskt mycket bedrövelse. Men nej det får jag inte göra nu, för jag ska ju dö snart.

Citatet visar på en konkret påminnelse från omgivningen om konsekvenserna av livets ändlighet. Det var inte i alla fall som omgivningens påminnelser var så konkreta. Det kunde också handla om diskreta frågor om testamenten eller fullmakter, men även uppriktiga samtal om hur en tänkt sig sin sista tid, i händelse av sjukdom eller liknande.

De sociala erfarenheterna av åldrandet kunde också handla om att komma till en klassåterförening och bli chockerad över hur "gamla" klasskompisarna framstod, både vad gäller beteende och utseende, för att senare, efter en stunds reflektion, dra slutsatsen: då är jag nog också gammal. I detta fall blir det en oangenäm känsla av att 
betrakta sig själv som äldre, eftersom en betraktar sina jämnåriga som äldre. Denna jämförelse med andra människor och andra människors åldrande har stor betydelse för hur individer uppfattar sitt eget åldrande och hälsa (Gilleard \& Higgs 2000; McHugh 2000; Jolanki 2009; Bennett \& Gaines 2010). Det blir ett sätt att spegla sig i andra för att skapa förståelse för och tolka sitt eget åldrande (Anderson, Lukkarinen Kvist, Nilsson m.fl. 2011). Gunnar återkom till denna anekdot om klassåterträffen vid flera tillfällen och återgav med stor inlevelse hur påtagligt hans eget åldrande hade blivit för honom när han såg sina gamla klasskompisar. Samtidigt kunde han inte riktigt identifiera sig med att vara gammal/äldre: "Det var ett gäng gamlingar och jag".

Informanterna speglade sig också i varandra när de samtalade om sitt åldrande. Det kunde aktualiseras som kommentarer, framför allt till den äldste deltagaren som var 90 år och fortfarande pigg och intellektuellt aktiv. Om honom fälldes ofta kommentarer som att han var "exceptionell" och "en förebild". Men det förekom också lite avståndstagande eller ursäktande kommentarer som att "alla kan ju inte vara som du".

En annan påminnelse om livets ändlighet är dödsannonserna i dagstidningen. Samtliga informanter menade att de med allt större intresse börjat läsa dödsannonserna för att leta efter bekanta namn. Även i Woodsprings (2016) studie pratar informanterna om hur betydelsefulla dessa dödsannonser är för deras självidentitet och känsla av att inte ha mycket tid kvar. Vännernas bortgång påminner om att de själva befinner sig i en fas i livet där döden blir ett naturligt inslag. Den är inte längre oväntad. Nedanstående reflektioner gjordes i samband med att vi diskuterade vad det innebär att vara "äldre".

Ola: Man läser dödsannonserna noggrant.

Ivar: Ja, det gör man.

Sanna: Faktiskt.

Ola: Och det är en jobbig sak också, tycker jag, att vännerna dör till höger och vänster. Så att man får...

Sanna: Ja, ett och annat namn.

Ivar: Ja, jag har känslan av att leva på övertid när jag tittar i dödsannonserna och det är någon slags tacksamhetskänsla att fortfarande få vara frisk och nyfiken på världen. Och få tid att liksom fördjupa mig i det som just kommer för mig, och inte vad som är beroende av att det är vissa saker jag måste göra. Det är en väldigt positiv känsla.

Aktiviteten att läsa dödsannonserna och leta efter kända namn kan förstärka det som Jaspers definierar som gränssituationer (1971[1938]). När informanterna ser att vännerna omkring dem dör blir livets ändlighet påtaglig för dem. Det är en påtaglighet som inte bara gör att informanterna reagerar när de råkar höra om vänners dödsfall, utan det har också ändrat deras sätt att läsa tidningen. De fokuserar nu alltmer på sidorna med dödsannonser, eftersom det för dem känns högst troligt att de kommer att finna kända namn där. Känslan av livets ändlighet medför dock inte enbart rädsla och oro. Gränssituationer kan också leda till positiva känslor och vara en positiv del i 
att "praktisera döende" (Jasper 1971[1938]; Baars 2017). Som synes i Ivars uttalande medför medvetenheten om livets ändlighet och den förestående döden en högre känsla av närvaro i nuet och tacksamhet för det vardagliga och lilla i livet. Vetskapen om att det kommer ta slut gör upplevelsen av att leva mer intensiv. Även om den konkreta döden inte längre sker i hemmen i samma utsträckning som tidigare och även om döendet alltmer blivit förknippat med hög ålder så blir döden en del av livet därför att föreställningarna och medvetenheten om den påverkar hur livet levs och erfars i nuet. Ändligheten finns där i medvetandet hos informanterna och påminner om det oundvikliga (Moran 2015) och blir därför en viktig faktor för hur informanterna upplever livet i nuet.

\section{Förkroppsligat åldrande och gränssituationer - att känna sig gammal}

Att vänja sig vid bilden av sig själv som äldre var något som återkom under fokusgrupptillfällena. Här fördes diskussionerna såväl utifrån en förkroppsligad dimension - hur jag känner av åldrandet i min kropp - som en social dimension - hur jag möter andras bild av mig som äldre. Det fanns en komplexitet i de här diskussionerna som kombinerade känslor av vemod med svårigheter att identifiera sig själv som äldre. Liksom i Woodsprings (2016) studie så återkommer informanterna till beskrivningar av hur tidens gång avtecknar sig i kroppen. Det är en förkroppsligad tid (Turner 1992, 1996) som blir synlig som rynkor i huden, grå hårstrån eller förändringar i muskulatur och ben som gör att kroppen känns annorlunda, "känns gammal". Vid ett av fokusgrupptillfällena, när informanterna flera gånger nämnt att de kände sig gamla utan att närmare konkretisera vad denna känsla innebar, så ställde jag frågan:

\section{I: Men vad är det som händer då när man känner sig gammal?}

Ivar: Då känner man sig gammal.

Bengt: Man går lite långsammare.

Eva: Man blir lite ledsen.

I: Ja, för jag tänker att det är något i den situationen där. Att man kommer på nånting?

Ivar: Ja, jag blir lite rädd. Jag inser att jag har fyra-fem år kvar att leva, sen är jag död.

Eva: Vad är du rädd för?

Ivar: Nej, men jag konstaterar det lite kallt.

Reflektionen innehöll såväl konkreta utsagor om att gå långsammare som vaga formuleringar om ledsamhet men också om rädsla som kopplades till en slutsats om att livet kanske bara skulle vara i fyra till fem år till. Den senare utsagan grundades i informantens höga ålder i jämförelse med den genomsnittliga livslängden. Det är samtidigt intressant att denna informant omformulerar sig när Eva frågar vad han är rädd för: "nej, men jag konstaterar det lite kallt". Vändningen kan vara ett uttryck för att detta samtal utspelade sig i en av de första fokusgruppdiskussionerna. Eftersom ämnet återkom vid flera senare tillfällen, när dynamiken i gruppen blivit mer förtrolig, 
så blev det dock allt tydligare att vemod och rädsla var något flera i gruppen delade. Det är en diskussion som, liksom ovan, innehöll känslor av vånda och rädsla men också känslor av tacksamhet inför nuet (Jaspers 1971[1938]; Baars 2017).

I analysen försökte jag finna samband mellan informanternas ålder och deras utsagor om närhet till slutet och livets ändlighet, men kunde inte se några klara mönster. Däremot sa en av kvinnorna, som var 84 år, vid ett tillfälle till en man som var 69 år: "vänta till du passerat 82 ! Det är en magisk gräns. Efter det går allt utför. Jag vill inte måla allt i svart för er nu, men så är det". Kommentaren kom i samband med att mannen hade uttalat sig positivt om möjligheterna efter pensionen och berättade om hur han var ute och reste med sin fru och inte upplevde något negativt med att vara äldre. Därefter utbröt en diskussion om ålder och åldrande. I denna diskussion var det inte kronologisk ålder utan snarare hälsa som framhölls som en viktig faktor för hur livet uppfattas, hur en upplever sitt eget åldrande och hur en reflekterar över livets ändlighet.

I resultatet som helhet verkar det också som att informanternas resonerande kring livets ändlighet och åldrandet rör sig i ett gränsområde mellan ålder, hälsa samt tidigare erfarenheter i livet av andras åldrande och välbefinnande. De fysiska förändringarna i kroppen blir en konstant påminnelse om tidens gång och i vissa fall en gradvis försämrad hälsa. Det kan vara i situationer när en försöker ta sig upp på cykeln och upptäcker att det inte längre går, eller när en är ute på promenad och upplever sig bli omsprungen av alla andra och inser att det egna tempot blivit allt långsammare. Kroppsliga förändringar, hälsa och det retrospektiva reflekterandet över erfarenheter i livet av andras åldrande blir således tre saker som påminner informanterna om livets ändlighet och döden, och hur tiden som är kvar blir allt kortare i förhållande till tiden som förflutit. När informanterna diskuterade ovanstående reflekterade de också kring de känslor som upplevelsen av åldrandet och ändligheten förde med sig.

Ivar: Och sen kan man ändå se det som en naturens ordning som man får anpassa sig till men ett slags, en stark vemodskänsla.

Linn: Och lite grann tänker jag: det är sista gången jag gör detta. Ivar: Ja.

Linn: Jag kan aldrig orka detta mer. Gå i fjällen eller sådana saker [...].

Att inte längre kunna göra det en varit van vid att göra tidigare bidrar till känslan av en gränssituation (Jasper 1971). En gränssituation som i ovanstående fall markerar en väg bort från det framgångsrika åldrandet till något annat, kanske "det onda åldrandet". På så sätt implicerar rörelsen också en rörelse bort från den friska, aktiva och ansvarstagande medborgaren till den passiva och sjukliga medborgaren i behov av samhällets omsorg (Katz 2000; Rozanova 2010; Timonen 2016).

Men det var inte bara den sviktande muskelstyrkan, att inte kunna ta sig upp på cykeln eller upptäcka att en blir omsprungen av omgivningen, som drog informanternas uppmärksamhet till det kroppsliga åldrandet. Det kunde även vara bemötandet från omgivningen. Det kunde handla om människor som reste sig på bussen för att ge dem sittplats, något som flera av dem hade ambivalenta känslor inför. Samtidigt som de 
uppskattade den vänliga gesten så fanns där en besvärande känsla av att vara en person som sågs som äldre och behövande. Om informanterna vanligtvis betraktade sig som framgångsrika i sitt åldrande, på så sätt att de höll sig aktiva och relativt ungdomliga, så blev dessa situationer en påminnelse om något annat som inte var framgångsrikt. Rörelsen från en livsfas till en annan blir inte bara en förflyttning i tid utan påverkar samtidigt informanternas självuppfattning och identitet (Turner 1996).

\section{Strategier för att ta kontroll över hur}

I informanternas diskussioner blev det tydligt att även om det kunde finnas ett vemod i insikten om att livets slut närmade sig, så var det inte den insikten som var källan till informanternas oro. Oron härrörde snarare från att inte veta hur vägen till slutet skulle se ut.

Eva: Nej, men det var lite det du sa som jag tänkte säga också. Först blir man kanske rädd, är jag så gammal och så. Men det är inte döden jag är så rädd för utan det är det som är före i värsta fall.

Bengt: Ja, precis.

Eva: Det vill jag inte gärna vara med om alls.

En strategi för att försöka ta kontroll över det ovissa hur, var att anamma doktriner om det framgångsrika åldrandet som ett sätt att skjuta dålig hälsa och "det oundvikliga" längre framför sig. Informanterna samtalade därför mycket om vikten av att hålla sig aktiv både fysiskt och mentalt, men också om att behålla ett ungdomligt yttre medelst krämer, smink, hårfärg och så vidare. När informanterna berättade om sitt användande av produkter var det dock snarast såsom en bekännelse av något som var pinsamt än något en var stolt över. I diskussionerna kom utseende och hälsa upp:

Linn: Jo, men jag erkänner. Jag läser $M$-magasin och sådana där tidningar och försöker hålla mig à jour. Jag tänker på vad jag har på mig och hur jag ser ut för att inte verka gammal, eller äldre än vad jag är. Gör inte ni det?

Eva: Jo, ja, lite tittar man väl.

Ola: Jag läser kanske inte $M$-magasin men nog tänker jag på vad jag har på mig och hur jag ser ut.

Sune: Ja, [vänder sig till Anders] och vi tränar ju, håller oss unga!

Att utseende och hälsa flyter samman i en otydlig definition av ett framgångsrikt åldrande är vanligt. Till viss del kan den diffusa gränsen mellan hälsa och utseende förstås utifrån det framgångsrika åldrandets starka koppling till ungdomlighet och en ungdomlig framtoning (Rozanova 2010; Timonen 2016). Att informanternas samtal pendlade obehindrat mellan utseende och hälsa som delar av en och samma enhet kan också förstås i relation till den kontrollerbara och okontrollerbara kroppen (Turner 1996). Liksom kvinnorna i studien av Ballard, Elstone och Gabe (2009) uttrycker informanterna i den här studien att utseendet är något som de känner att de kan kon- 
trollera med hjälp av krämer, smink och kläder. Däremot fanns det andra kroppsliga förändringar, som exempelvis sviktande hälsa och muskelstyrka, som de inte kände att de hade samma kontroll över; snarare menade de att det var kroppen som hade kontroll över dem. Dock gjorde informanterna vad de kunde för att kontrollera även hälsa och muskelstyrka. Detta kom till uttryck i de många utsagorna om träning och aktivitet. Att inte vara aktiv uttrycktes som ett sätt att bjuda in dålig hälsa och död.

Sune: Ligga till last ja det, precis det kan göra en bitter i allra högsta grad och sen kan det ju också ge den här viljan att ge upp och det kan jag ju känna själv i dag med den här tröttheten som jag har och alla möjliga problem att jag ger upp och då hamnar jag i det som en sjukgymnast sa att: sängen är hälsans värsta fiende. Så är det och det är oavsett ålder, men visst stor risk är det ju att man bara försvinner om man stannar kvar i sängen.

Jag tolkar citatet som ett uttryck för en kombination av rädsla att bli beroende av andra och en vilja att ta kontroll över sitt eget åldrande och döende. Att hålla sig aktiv och träna beskrivs som framgångsfaktorer för att ta kontroll över den egna hälsan och det egna åldrandet och i kontrast till detta ses passivitet och att ligga till last som misslyckanden. Resonemanget kan ses som ett uttryck för utsagor om det framgångsrika åldrandet (Rozanova 2010; Timonen 2016) och informantens vilja att ta kontroll över sin hälsa och åldras framgångsrikt. Det är en vilja som samtidigt utgår från en hotbild och professionellas utsagor om sängen som hälsans värsta fiende. Viljan är således inte något odelat positivt utan grundas i även i en känsla av ett måste som både handlar om att ta kontroll över den egna hälsan för sin egen skull och om att inte ligga andra till last.

I detta resonemang blir kontroll en viktig faktor. Kontroll över sin kropp och sin död. En av informanterna drog denna kontroll till sin yttersta spets och lyfte vid ett flertal tillfällen frågan om dödshjälp.

Sune: Men det du berättar här Erik det återföder en tanke hos mig som kommer med jämna mellanrum och framför allt är det därför att min bonusson han är femtio snart. Hans svärfar fick en tumör i skallen 1999. Han lever fortfarande. Han känner inte igen sin fru. Han känner inte igen sina barn. Han lever isolerad på ett vårdhem. Och då tänker jag. I Nederländerna och Schweiz där har de ett piller som gör att man kan ta och avsluta själv. Livet. Jag tycker vi ska införa det faktiskt. Det är lämpligt att man gör, men det är ju svårt för dem, din svärmor att besluta det.

I det här citatet återkommer utsagor om framgångsrika strategier och en berättelse om bonussonen som får stå för det misslyckade. I fokus är alltjämt kontroll och förlusten av kontroll. Informantens utsagor om aktiv dödshjälp mötte varierad respons. Det var långt ifrån alla som var eniga med honom. De flesta var skeptiska till hur det skulle kunna genomföras på ett säkert sätt. Någon uttryckte sig i termer av att: "om du inte 
vet att det är säkert, om sjukvården skulle börja med dödshjälp som ett sätt att effektivisera eller spara pengar då är det ju ändå inte du som beslutar”. Andra informanter fyllde i med diskussioner om risken att närstående skulle använda dödshjälp som ett sätt att avsluta ens liv för att de är intresserade av arv eller dylikt. Samtliga verkade de överens i sin vilja att kontrollera sitt eget döende men de kunde inte nå fram till en konkretisering av hur det skulle kunna gå till på ett säkert sätt. Kanske för att det inte går att kontrollera livets ändlighet?

Informanternas resonemang påminner till viss del om den diskussion som förs $\mathrm{i}$ Lamers och Williams (2016) studie av hur äldre förhåller sig till assisterad dödshjälp och eutanasi i Storbritannien. Agens och viljan till kontroll över sitt eget liv är ett förkommande inslag även där och informanterna i deras studie hänvisade till sin rätt till autonomi och det fria valet. Däremot finns det en skepsis mot såväl sjukvårdspersonal som anhöriga hos informanterna i den här studien, vilket är något som inte återfinns i Lamers och Williams (2016) studie. Faktumet att någon annan med mer kompetens kunde fatta det slutgiltiga avgörandet var i deras studie något som informanterna snarare förknippade med trygghet (ibid.).

Andra sätt att administrera sitt hur som informanterna använde sig av var att skriva tydliga instruktioner för hur de ville bli vårdade i livets slutskede.

Eva: Däremot jag har skrivit en lapp som sitter väl synlig i min pärm att om jag hamnar i situationen att det inte går att finna någon bot och, ja ni förstår, och man har starka smärtor och så, då vill jag ha maximal smärtlindring även om det avkortar livet. Att inte bli hållen till liv med slangar och sprutor och grejer och helt uppkopplad till sånt. Jag vet inte, det var någon granne som sa det där, att man bör ha ett sånt papper för att annars så kan man bli hållen vid liv.

Dan: Du menar att dina släktingar kan inte begära det, utan det här måste man ha själv?

Eva: Ja, och det skall vara undertecknat.

Bengt: Och vittne också.

Eva: Ja, två personer har undertecknat det här pappret. Min granne, som gav det till mig, hade väl talat med några som vet. Så kopierade jag hennes. Så det har jag i min pärm med räkningar, för jag är så omodern att jag betalar fortfarande [...].

Att som i citatet skriva testamente eller instruktioner för hur en vill vårdas för att ta kontroll över vad som ska ske när en inte längre är medelbar var något som diskuterades ingående. Det fanns en tydlig rädsla för att bli beroende av andras viljor och tyckande i livets slutskede, något de observerat hos vänner och släktningar. Till viss del finns det beröringspunkter med resultaten i Meier med flera (2016) och resonemangen om "framgångsrikt åldrande" utifrån faktorer som värdighet, frånvaro av smärta samt att få ha kontroll över hur en blir vårdad och hur en dör. Men jag ser också något mer i informanternas utsagor, något som tydligare relaterar till samhälleliga normer om det framgångsrika åldrandet. På liknade sätt som det hävdas att framgångsrikt åldrande innebär att det aktiva åldrandet blivit en skyldighet (Rozanova 2010; Timonen 2016) 
ger informanterna uttryck för värderingar där den framgångsrika döden har blivit en skyldighet eller $i$ alla fall i hög utsträckning individens ansvar. Föreställningarna om den framgångsrika döden är inte enbart grundande i individens behov utan innehåller även kollektiva normerande aspekter som kommer till uttryck i att inte vilja ligga andra till last, eller i behovet av att vara ungdomlig och aktiv intill döden.

\section{Slutdiskussion}

Ändligheten visade sig vara något som samtliga informanter förhöll sig till så gott som dagligen och utifrån flera dimensioner. Ändligheten gjorde sig påmind via förändringar i kroppen såväl som i sociala situationer med andra. Dessa påminnelser markerade gränssituationer (Jaspers 1971[1938]) som för informanterna också synliggjorde övergången från en livsfas till en annan. Det handlade både om det förkroppsligade åldrandet, det sociala åldrandet och det biografiska åldrandet (Andersson, Lukkarinen Kvist, Nilsson m.fl. 2011), vilka sammantaget bildade tolkningsramarna för hur de förhöll sig till sitt eget åldrande och föreställde sig sin egen framtid.

Det fanns hos informanterna en stor osäkerhet och även en rädsla inför ovissheten (hur) (Moran 2015) i framtiden. De uttryckte också att det kändes som att olika aspekter av framför allt det kroppsliga åldrandet var utom deras kontroll. Det var något som kroppen gjorde mot dem, en del av naturens gång och därmed en del av det oundvikliga. Ovissheten kombinerades med en vilja att ta kontroll över hur det framtida åldrandet, men även den framtida döden, skulle te sig. Därför diskuterade informanterna vikten av ett aktivt åldrande och att sängen och passiviteten var hälsans största fiende. Det var tydligt att de såg ett stort egenansvar i att förlänga antalet friska år genom att träna och hålla sig aktiva, såväl kroppsligt som mentalt.

Liksom informanterna i Woodsprings (2016) studie, uttryckte informanterna i den här studien en vilja att ta kontroll över det egna döendet. Att ha kontroll över sin hälsa, sitt åldrande och till och med vården i livets slutskede lyfts fram som framgångsfaktorer på ett sätt som gör att jag drar slutsatsen att det inte enbart handlar om utsagor om ett framgångsrikt åldrande (Rozanova 2010; Timonen 2016) utan även om ett framgångsrikt döende. Viljan kunde uttryckas på olika sätt, genom utsagor om aktiv dödshjälp, genom en rädsla för att bli passiv och sjuk så att en förlorar kontrollen över sig själv och blir beroende av andra eller genom framåtsyftande åtgärder som att skriva testamenten, vittnesmål eller instruktioner om hur en vill bli vårdad i slutskedet.

Döden är således högst påtaglig i informanternas liv i nuet - den är något som ska skjutas upp, planeras och administreras med den sorts självdisciplinerande tekniker som diskuteras av Turner $(1992,1996)$. Det blir en förlängning av teknikerna i det framgångsrika och aktiva åldrandet som också kommer att omfatta livets ändlighet och döden. På så sätt kan en likt Baars $(2016,2017)$ hävda att informanterna "praktiserar döende" som en integrerad del av sina aktiva liv.

Det förelåg samtidigt en medvetenhet om att det inte gick att ta fullständig kontroll över livsloppet och livets ändlighet, men insikten om att människan till viss del kan försöka och lyckas kontrollera delar av åldrandet och hälsan bidrog till en diskussion 
om skyldigheten att göra aktiva val och administrera sin tid. I viss mån verkade dessa små utrymmen av kontroll inge en viss trygghet inför det faktum att livet är ändligt och att slutet närmar sig. Därmed blir de olika teknikerna som träning, att skriva testamente och så vidare, sätt att hantera de egna rädslorna inför det som annars framstod som en ovisshet.

\section{Referenser}

Andersson, J., M. Lukkarinen Kvist, M. Nilsson \& A.-L. Närvänen (2011) Att leva med tiden. Sambälls- och kulturanalytiska perspektiv på ålder och åldrande. Lund: Studentlitteratur.

Baars, J. (2016) "Aging. Learning to live a finite life", The Gerontologist 57 (5):969-976. https://doi.org/10.1093/geront/gnw089

Baars, J. (2017) "Human aging, finite lives and the idealization of clocks", Biogerontology 18:285-292. https://doi.org/10.1007/s10522-016-9664-6

Ballard, K.D., M.-A. Elstone \& J. Gabe (2009) "Private and public ageing in the UK: The transition through the menopause", Current Sociology 57 (2):269-290. https:// doi.org/10.1177/0011392108099166

Bennett T. \& J. Gaines (2010) "Believing what you hear. The impact of aging stereotypes upon the old", Educational Gerontology 36 (5):435-445. https://doi. org/10.1080/03601270903212336

Bryman, A. (2016) Samhällsvetenskapliga metoder. Stockholm: Liber.

Dahlin-Ivanoff, S. (2018) "Fokusgruppsdiskussioner", 81-92 i G. Ahrne \& P. Svensson (red.) Handbok i kvalitativa metoder. Stockholm: Liber.

Elchardus, M. \& W. Smits (2006) "The persistence of the standardized life cycle", Time \& Society 15 (2-3):303-326. https://doi.org/10.1177/0961463x06066944

Gilleard, C. \& P. Higgs (2000) Cultures of ageing. Self, citizen and the body. London: Routledge. https://doi.org/10.4324/9781315839530

Janssen, S., M. Naka \& W.J. Friedman (2013) "Why does life appear to speed up as people get older? ”, Time \& Society 22 (2):274-290. https://doi. org/10.1177/0961463x13478052

Jaspers, K. (1971[1938]) Philosophy of existence. Philadelphia: University of Pennsylvania Press.

Jolanki, O.H. (2009). "Agency in talk about old age and health", Journal of Aging Studies 23 (4):215-226. https://doi.org/10.1016/j.jaging.2007.12.020

Katz, S. (2000) "Busy bodies. Activity, aging and the management of everyday life", Journal of Aging Studies 14 (2):135-152. https://doi.org/10.1016/s0890-4065(00)80008-0

Lamers, C.P.T. \& R.R. Williams (2016) "Older people's discourses about euthanasia and assisted suicide. A Foucauldian exploration", The Gerontologist 56 (6):10721081. https://doi.org/10.1093/geront/gnv102

Leishman, J. \& J. Moir (2009) Perspectives on death and dying. Keswick: M\&K Publishing.

McHugh, K.E. (2000) ”The 'ageless self’? Emplacement of identities in sun belt retire- 
ment communities", Journal of Aging Studies 14 (1):103-115. https://doi.org/10.1016/ s0890-4065(00)80018-3

Meier, E.A., J.V. Gallegos, L.P. Montross Thomas, C.A. Depp, S.A. Irwin \& D.V. Jeste (2016) "Defining a good death (successful dying). Literature review and a call for research and public dialogue", The American Journal of Geriatric Psychiatry (24) 4:261-271. https://doi.org/10.1016/j.jagp.2016.01.135

Moran, C. (2015) "Time as a social practice", Time \& Society 24 (3):283-303. https:// doi.org/10.1177/0961463X13478051

Rozanova J. (2010) "Discourse of successful aging in The Globe \& Mail. Insights from critical gerontology", Journal of Aging Studies 24 (4):213-222. https://doi. org/10.1016/j.jaging.2010.05.001

Rowe J.W. \& R.L. Kahn (1997) "Successful aging", The Gerontologist 37 (4):433-440. https://doi.org/10.1093/geront/37.4.433

Turner, B.S. (1996) The body and society. Explorations in social theory. London: Sage.

Turner, B.S. (1992) Regulating bodies. Essays in medical sociology. London: Routledge. https://doi.org/10.4324/9780203214183

Timonen, V. (2016). Beyond successful and active ageing. A theory of model ageing. Bristol: Policy Press.

Turner B.S. (1987) Medical power and social knowledge. Sage Publications: London

Weiss, D. \& F.R. Lang (2012) '”'They' are old but 'I' feel younger. Age-group dissociation as a self-protective strategy in old age", Psychology and Aging 27 (1):153-163. https://doi.org/10.1037/a0024887

Weiss, D. (2014) "What will remain when we are gone? Finitude and generation identity in the second half of life", Psychology and Aging 29 (3):554-562. https:// doi.org/10.1037/a0036728

Woodspring, N. (2016) Baby boomers. Time and ageing bodies. Bristol: Policy Press. https://doi.org/10.1332/policypress/9781447318774.001.0001

\section{Författarpresentation}

Janicke Andersson är docent i sociologi och lektor i socialt arbete vid Högskolan i Halmstad. Hennes forskningsintressen är åldersnormer och åldersstrukturer i samhället, det förkroppsligade åldrandet samt åldrandets idéhistoria i relation till makt och styrning.

\section{Kontaktuppgifter författare}

Janicke Andersson

Akademin för hälsa och välfärd

Högskolan i Halmstad, Box 823, 30118 Halmstad

janicke.andersson@hh.se 